\title{
Incidence of the source of fibre on the caecal fermentation pattern of the growing rabbit
}

\author{
R Bellier, T Gidenne
}

INRA, Station de Recherches Cunicoles, BP 27, 31326 Castanet-Tolosan, France

The level of the dietary fibre (DF) intake as well as cell-wall components (cellulose, lignin...) cause changes in the caecal fermentation either in term of volatile fatty acids (VFA) concentrations or in VFA proportions (Gidenne et al, 1990, Ann Zootech, 40, 73-84). The aim of this study was to control if the origin of the fibre source, in diets containing similar content in the different cell-wall fractions, could influence the caecal fermentation and the fibre degradation in the growing rabbit.

Three experimental diets were given ad libitum in a pelleted form to three groups of nine rabbits cannulated at the caecum. The diets were similar in their NDF content $(320 \mathrm{~g} / \mathrm{kg}$ MS) and in the respective proportions of cellwall fractions (hemicelluloses "NDF-ADF" $=54$ $\%$, cellulose "ADF-ADL" $=37 \%$, lignin "ADL" $=9 \%$ ), but they differed mainly by the fibre origin : Lucerne (diet L), sunflower meal (diet SM), wheat straw (diet WS). Digestibility measurement and caecal digesta sampling were performed at seven weeks of age, after a three week adaptation period to the diets.

As a consequence of the similar DF content, the dietary intake was similar among the three groups. The organic matter (OM) digestibility was significantly higher for the diet $S M$, but this was not related to fibre digestibility that remained similar between the diets. Furthermore, the quantity of NDF degraded was significantly lower for SM (3.7 g NDF/d) compared to $L$ and WS groups (5.0 g NDF/d). Compared to $L$ group, a significantly lower VFA concentration was found for WS group. As in the WS diet wheat straw was the only source of fibre, we supposed that a lack of diversity in the fibre source could reduce caecal fermentations. The proportions of the different VFA were not affected by the diets and were close to those reported for the rabbit (meanly : acetate $=85.8$ $\%$, propionate $=5.5 \%$, butyrate $=8.3 \%$ ). Caecal $\mathrm{pH}$ and $\mathrm{NH}_{3}$ concentrations were similar between the diets, and no correlation was found between caecal $\mathrm{pH}$ and ammonia and total VFA concentrations.

In conclusion, the botanical origin of cell wall could affect fibre degradation and the caecal fermentation pattern in the rabbit, even when the different cell-wall fractions were provided in similar quantity.

\begin{tabular}{|c|c|c|c|c|c|c|}
\hline \multirow[t]{2}{*}{ Diets } & \multirow{2}{*}{$\begin{array}{c}\text { DM intake } \\
(\mathrm{g} / \mathrm{d})\end{array}$} & \multicolumn{2}{|c|}{ Digestibility (\%) } & \multirow{2}{*}{$\begin{array}{c}\text { Caecal } \\
\mathrm{pH}\end{array}$} & \multirow{2}{*}{$\begin{array}{c}\text { Total VFA } \\
(\mathrm{mmol} / \mathrm{l})\end{array}$} & \multirow{2}{*}{$\begin{array}{c}\mathrm{NH}_{3} \\
(\mathrm{mmol} / \mathrm{l})\end{array}$} \\
\hline & & OM & NDF & & & \\
\hline $\mathrm{L}$ & 69.8 & $63.8^{a}$ & 24.4 & 6.34 & $61.2^{a}$ & 6.1 \\
\hline SM & 70.9 & $67.0^{\mathrm{b}}$ & 19.7 & 6.58 & $56.6^{\mathrm{ab}}$ & 4.1 \\
\hline WS & 75.2 & $64.7^{a}$ & 22.3 & 6.59 & $51.1^{b}$ & 5.4 \\
\hline $\mathrm{P}:$ & NS & 0.01 & 0.11 & NS & 0.04 & NS \\
\hline
\end{tabular}

NS : not significant $P>0.2$ 